\title{
DE OPLEIDING EN DE POSITIE VAN DEN DISTRICTSGENEESHEER IN SURINAME
}

DOOR

\author{
C. BONNE
}

De geneeskundige school is aanvankelijk opgericht met het doel te voorzien in de behoefte aan geneeskundige hulp voor de immigranten. Van tropische hygiëne, de zorg niet alleen voor de zieken, maar voor den gezondheidstoestand in het algemeen, was toen nog nauwelijks sprake; in het leerplan van de school en in de praktische opleiding stond de hygiëne ver op den achtergrond en ze staat daar betrekkelijk nog. De districtsgeneesheer behandelt de zieken in zijn district en daarmede uit.

De Surinaamsche geneesheer heeft het recht zijn studies in Nederland voort te zetten. Als hij in Nederland het artsdiploma heeft behaald heeft hij alle rechten verkregen van den arts, die zijn volledige opleiding in Nederland heeft gehad. Terwijl zijn Surinaamsche diploma hem alleen het recht gaf in West-Indië praktijk uit te oefenen, staat met het Nederlandsche diploma bij wijze van spreken de wereld voor hem open.

Daarmee is het dualistisch karakter der opleiding aan de geneeskundige school reeds aangeduid. Aan de eene zijde een opleiding gericht op de belangen van Suriname, waarbij specifieke kennis van Surinaamsche ziekten op den voorgrond moest staan, aan de andere zijde een opleiding gericht op de belangen van den Surinaamschen geneesheer, waarbij het oog wordt gericht op zijn verdere opleiding in Nederland. Zonder twijfel staat de laatste richting op den voorgrond en hoe vreemd het moge schijnen, de opleiding in de kennis der tropische Surinaamsche ziekten is een der zwakste plekken van het onderwijs aan de geneeskundige school. 
De redenen, die daartoe voeren zijn velerlei. In de eerste plaats gaat de belangstelling van den leerling der school al meer naar Nederland dan naar Suriname. Wanneer hij zich zijn ideaal in de toekomst voorstelt, dan is dit niet een permanente positie als districtsgeneesheer, maar dan droomt hij van een loopbaan na voleindigde studie aan een werkelijke universiteit. In den regel denkt hij daarbij niet aan terugkeer naar Suriname en zeker niet als districtsgeneesheer. Natuurlijk wordt dit ideaal niet steeds bereikt, maar dat hij zijn ideaal niet plaatst in het district is begrijpelijk. De positie van districtsgeneesheer toch is weinig aanlokkelijk; het salaris is onvoldoende, een groot deel van den tijd moet worden doorgebracht met reizen in barkassen op de rivieren. Veel resultaten kunnen niet worden bereikt, omdat zijn hulpmiddelen primitief zijn, voldoening door hygiënisch werk is er moeilijk verkrijgbaar. Nu zou er in dit laatste opzicht zeker meer kunnen worden gepresteerd dan thans, maar men moet niet vergeten, dat er voor den districtsgeneesheer absoluut geen voordeel aan is verbonden zich in te spannen tot het bereiken van hygiënische resultaten. Niet voor zijn onmiddellijke positie en nauwelijks voor zijn toekomst maakt het eenig verschil of hij bijv. zijn best doet de bevolking van zijn district van ankylostomen of malaria te bevrijden. En het salaris van den districtsgeneesheer is zoo karig, dat zijn eerste belangstelling uitgaat naar vermeerdering van inkomsten door praktijk onder particulieren.

Het weinig aanlokkelijke van zijn positie in het district sterkt hem in zijn voornemen naar Nederland te gaan om af te studeeren, waarna zijn toekomst verzekerd is. Daarvoor heeft hij geld noodig, en al zijn inspanning richt zich dus op het verkrijgen van bijverdiensten, waaronder de hygiënische zorg voor den gezondheidstoestand van de bevolking van zijn district, die niet wordt betaald, zonder twijfel lijdt. Psychologisch is dit zeer begrijpelijk. Als regel zal iemand eerst dan zijn werkkracht in dienst stellen van werk dat niet betaalt, als hij een behoorlijk inkomen heeft, tenzij dit werk toevallig ligt in de lijn van zijn persoonlijke voorkeur. 
Het ontbreken van een behoorlijk inkomen en de geringe gelegenheid tot het ervaren van voldoening in zijn werk, maakt den districtsgeneesheer tot een mopperend en ontevreden wezen. Met zorg ziet hij vaak zijn gezin groeien, en het wordt steeds moeilijker voor hem in Nederland uitkomst te zoeken. Deze toestand, waarop natuurlijk wel een enkele uitzondering voorkomt, werpt in zekeren zin zijn schaduw reeds vooruit op de leerlingen der geneeskundige school.

De geneeskundige school moet hiermede rekening houden. Men kan niet teruggaan tot het oorspronkelijk standpunt en in de leerlingen alleen toekomstige geneesheeren in de districten van Suriname zien. De school heeft haar dualistisch karakter gekregen, dit is wettelijk vastgelegd en het zou een onbillijkheid zijn tegenover de bevolking van Suriname dit te ontkennen.

Bovendien sturen in het algemeen de leeraren vanzelf het onderwijs in Nederlandsche richting. In den regel toch zijn dezen sinds kort uit Nederland gekomen, en zullen zij dus onderwijs geven naar hun beste vermogen in den geest zooals ze dit in Nederland genoten hebben. Eerst locale ervaring zal hen doen inzien, dat wat elders belangrijk is, in Suriname soms zonder beteekenis kan zijn en omgekeerd.

Het resultaat is dat de geneeskundige school in hoofdzaak is geworden een opleiding in aansluiting met het medisch universitair onderwijs in Nederland en dat de afgestudeerde jongelui, indien zij niet over voldoende middelen beschikken om direct naar Nederland te gaan min of meer noodgedwongen de positie van den districtsgeneesheer aanvaarden om zich de noodige fondsen daartoe te verschaffen. De positie in het district is slechts middel, geen doel. Dit resultaat is mijnsinziens niet zooals het zijn moest en eenige verbetering daarin is toch wel denkbaar.

Verbetering, zoodat de Surinaamsche geneesheer, ook de beste onder hen, zich althans gedurende een reeks van jaren, waarin zijn kinderen nog niet naar school behoeven te gaan, in het district op zijn plaats voelt, lijkt mij mogelijk langs de volgende lijnen. 
In de eerste plaats moet het salaris worden verbeterd, zoodat materiëel althans de grootste zorgen verdwenen zijn. Daarmee alleen is men er echter niet, want blijft de rest onveranderd, dan zal het resultaat zijn, dat de districtsgeneesheer nog iets vlugger dan thans naar Nederland verdwijnt. Er moet iets in zijn positie en in zijn werk veranderen, waardoor hij niet zoo spoedig vertrekt of waardoor het regel wordt dat hij als Nederlandsch arts weer terug komt. Dit kan alleen indien er meer mogelijkheid op voldoening komt in zijn werk. Het kan zijn: voldoening over zijn medisch handelen of wel voldoening over zijn hygiënisch werk. Daarvoor is noodig concentratie van de districtsposten. Zoolang de districtsgeneesheer zijn tijd moet verknoeien met in barkassen op de rivier te zitten, blijft hij een ouderwetsche koorts-kinine-automaat zonder gelegenheid tot behoorlijk onderzoek, observatie en behandeling zijner zieken. Dat centralisatie der plantage-hospitalen gewenscht is behoeft geen verdediging meer. Maar ook voor de vrije districtsbevolking zou de toestand beter worden. Men moet het denkbeeld loslaten, dat het 't beste voor den ernstigen zieke is, dat de dokter bij hem thuis den pols komt voelen. Behoorlijk onderzoek, behoorlijke verpleging, behoorlijke behandeling is slechts mogelijk in een behoorlijke omgeving onder het onmiddellijk toezicht van den dokter. Voor 99\% der districtsbevolking wil dit zeggen in een hospitaal. De dokter doet zijn werk daar beter en vlugger. De zieken moeten dus bij den dokter komen in zijn hospitaal en niet omgekeerd. Dat dit voor enkele, meer met aardsche goederen gezegende personen niet noodig is, en dat ook voor de overigen wel eens een uitzonderingsgeval voorkomt, mag geen reden zijn dit algemeene standpunt los te laten. Men moet den dienst inrichten naar de werkelijke belangen van de meerderheid der bevolking of deze rijk is of arm. En bij de overgroote meerderheid der districtsbevolking komt van behoorlijke behandeling en verpleging thuis met vluchtige bezoeken van den dokter enkele malen 's weeks niets terecht. De districtsbewoners zelven mogen er niet allen van overtuigd zijn, hun werkelijk 
belang brengt mee de zieken te concentreeren in een hospitaal. In die richting moet de bevolking worden opgevoed, zoolang ze stáat op het lage economische peil van thans. Dat de vrije bevolking, ik bedoel de bezitters of huurders van grondjes, voor die verpleging wil betalen is mij te Moengo gebleken. Maar men moet zich aanpassen aan de gewoonten der bevolking. De gewone methode was dat de familie den zieke bracht en tegelijk een lading veldvruchten. Deze werden verkocht en uit de opbrengst ineens een som gestort voor de verpleging van den zieke. Bij concentratie der districtsposten zou de zetel van een districtsgeneesheer allicht ook gekozen worden op een punt waar tuin- of landbouwproducten verkocht konden worden.

Met de behandeling van zijn zieken in een behoorlijk hospitaal is de geneesheer echter niet klaar, daarmee is slechts de helft van zijn werk verricht, gewoonlijk de kleinste helft. Bovendien moet hij zorg dragen voor den hygiënischen toestand zoowel op plantages als op grondjes en vestigingsplaatsen in zijn gebied. Men mag daarover de schouders ophalen en denken, dat daarvan toch nooit iets terecht komt, maar dan doet men dit toch eigenlijk, omdat men òf den bestaanden toestand een Augiasstal vindt òf omdat men tegenwerking verwacht van plantagedirecteuren of vrije bevolking, òf omdat men geen vertrouwen heeft in den Surinaamschen geneesheer. In het laatste geval is het beter er rond voor uit te komen en te adviseeren de geneeskundige school te sluiten, in het eerste geval zal men bij verder doordenken toch moeten inzien, dat men juist een Augiasstal niet ongemoeid mag laten, en wat medewerking betreft zullen op den duur de onwillige plantages door de publieke meening aan de schandpaal worden gezet en dan zal het bestuur niet aarzelen enkele bepalingen uit geneeskundige verordeningen strenger toe te passen, wat trouwens ook geldt tegenover vrije personen.

De districtsgeneesheer moet niet alleen de yawspatienten inspuiten, die hij toevallig ziet, maar hij moet de yaws uitroeien in zijn district, hij moet systematisch zijn 
malaria- en ankylostomen-dienst inrichten, hij moet systematisch de schurft uitroeien onder zijn immigranten, de leprapatiënten opsporen, zorgen zijn typhus- en dysenteriepatiënten te isoleeren en hun omgeving blijven controleeren. Al deze dingen kunnen met hoegenaamd geen kosten of lasten voor de plantages geschieden, mits de geneesheer maar het noodige „feu sacré” heeft en indien de tijden wat gunstiger worden kan hij er door gecontroleerde terrein-verbetering en privatenbouw hier en daar waarschijnlijk veel toe bijdragen om malaria en ankylostomeninfecties tegen te gaan. Misschien op een grootere plantage later eens een centraal waterleidinkje controleeren. De faecaliënafvoer zal voortdurend zijn controle noodig hebben. Hij moet verplicht zijn den vaccinatietoestand gunstig te houden en de controle erop moet niet alleen aan de school worden overgelaten. Op die wijze is er wat te doen en wat te bereiken. En dan moet de ijver ook beloond kunnen worden doordat de mogelijkheid openstaat voor beter, hooger en aantrekkelijker posities. De geneeskundige school reeds zal meer aandacht dan thans aan de tropische hygiëne, vooral aan de praktijk ervan moeten geven. Wanneer eenmaal het militair hospitaal en organisch onderdeel van den burgerlijk geneeskundigen dienst is geworden, zullen de districtsgeneesheeren van tijd tot tijd er kunnen worden gédetacheerd om hun kennis op te frisschen en ook de meest geschikten er jaren lang blijvende posities kunnen verkrijgen. Voor de meer hygiënisch voelenden zouden enkele goede posities als hygiënische werkers in Paramaribo beschikbaar komen. Ik zie geen reden, waarom later niet een uitblinkend hygiënisch aangelegd districtsgeneesheer, die wat meer van de wereld heeft gezien dan Suriname alleen, geneeskundig inspecteur zou kunnen worden. Op die wijze komt er meer perspectief in de positie van districtsgeneesheer en met eenige variatie tevens in die van stadsgeneesheer. Zoo kan het worden een betrekking, die de geneesheeren aantrekt in plaats van hen afstoot. En zoo kan iets goeds groeien uit den rommeligen toestand van thans, die nochtans talrijke elementen voor een goede hygiënische verzorging bevat, 
zooals een goed centraal gelegen hospitaal in Paramaribo met een goed laboratorium, een prachtig hospitaal voor besmettelijke zieken, enkele hygiënische poliklinieken, een reeds bestaand centraal bureau, een reeds bestaande voorloopige organisatie van geneesheeren in het district en in de stad, een reeds vrij ver doorgevoerde propaganda en een modeldorp als Moengo tot voorbeeld. Maar alles moet samengesmolten worden tot een organisch geheel van hygiënische organisatie, dat door een krachtige hand bijeengehouden, dichter nadert tot het wachtwoord van onzen tijd „Efficiency”.

Wie meent, dat men zich toch eigenlijk niet zoo druk behoeft te maken over den gezondheistoestand van Suriname, omdat er in de nabijheid enkele landen liggen met hooger sterftecijfer en omdat speciaal in de districten de sterfte betrekkelijk gunstig is, hij zij gewaarschuwd voor struisvogelpolitiek. Door voortdurende aanvoer van Aziaten wordt Suriname geleidelijk een Oostersch land met kansen op Oostersche epidemieën. De samenstelling der bevolking naar leeftijdsgroepen wordt sterk beïnvloed door voortdurende immigratie en terugzending naar Java, Bij een meer normale samenstelling der bevolking zou bij dezelfde hygiënische verhoudingen de sterfte hooger zijn. Dit is evenwel een kwestie van medische statistiek, waarop ik niet verder wil ingaan. Ik wil er slechts op wijzen, dat het sterftecijfer alleen geen maatstaf is voor het beoordeelen van den hygiënischen toestand.

En wie meent, dat het resultaat der voorgestelde maatregelen een opeenstapeling van blijvende hooge uitgaven zou zijn, vergist zich. Integendeel, er is op sommige punten ruimte voor bezuiniging. Bovendien geldt nog steeds, dat een wijs geleide hygiëne op den duur bespaart. 